\title{
The Impaction of Sino-US Trade War on Energy Trade and Countermeasures
}

\author{
Hui Shi ${ }^{1, a}$ \\ ${ }^{1}$ School of economics and management, Beijing Jiaotong University, Beijing, China
}

\begin{abstract}
In recent years, Sino-US trade friction has been escalating, and the Sino-US trade war in 2018 has officially sounded the alarm[1]. As one of the key links, energy trade is difficult to stand alone in this trade war. In terms of energy, technology and talents in the oil, gas and energy industries are likely to be affected. In order to deal with the impact of the trade war, China should broaden the energy import channels to ensure the energy import supply; accelerate the reform of state-owned enterprises in the energy industry to enhance the international competitiveness of products; increase investment in scientific research to promote energy technology innovation and scientific research personnel training and analyze the core issues of Sino-US trade war and look for the possibility of future cooperation.
\end{abstract}

\section{Introduction}

In November 2017, China and the United States signed a two-way investment agreement on energy cooperation projects, and the energy cooperation between China and the United States was reached. However, such a situation did not last long. After Trump came to power in 2018, the United States began to pursue the main body of trade protection, intending to break the original structure of international trade organizations and launch a Sino-US trade war. As a result, Sino-US trade relations have become increasingly tense. In recent years, the success of shale oil and gas revolution in the United States has achieved energy independence, and its energy trade policy has also changed greatly. Therefore, in order to reach a consensus on energy trade, China must create advantages in the negotiations and stabilize the US side with equal interests. In this context, it is urgent to analyze the impact of Sino-US trade friction on energy trade and to think about the future development of the relationship.

\section{The development of Sino-US trade war}

Since China's reform and opening up in 1978, China's economic aggregate has achieved leapfrog development. China's participation in the value chain of world products and its international status are increasing day by day, which has brought a serious sense of crisis to the United States. In addition, in recent years, the US trade deficit has continued to expand, reaching US \$375.2 billion in 2017. In order to maintain its own development and curb China's rise, the United States has launched a series of sanctions against China's foreign trade products. From the antidumping cases of WTO statistics from 1995 to 2018, it can be seen that the number of anti-dumping cases suffered by China is far ahead. In March 2018, the Sino0US trade war intensified. On March 8, trump signed the "232 measures" to impose $25 \%$ and $10 \%$ tariffs on imported steel and aluminum products respectively; on March 22, trump signed a memorandum, which made the relevant departments levy $25 \%$ tariff on imports of US $\$ 50$ billion products from China according to the 301 investigation report on China, which officially sounded the alarm of the trade war between China and the United States[2].

At the beginning of the reform and opening up, China was limited by the level of technology, and mainly relied on extensive production and low efficiency energy utilization to maintain its own development, which caused the excessive consumption of our own resources. In addition, China's original energy resource endowment is "rich in coal, lack of oil and gas", and oil and natural gas account for less than $10 \%$. However, China is a big manufacturing country, and its consumption of crude oil and natural gas has always been at the leading level in the world. In recent years, energy demand has continued to grow, so we must rely on a large number of imports to meet China's growing energy demand. China's traditional energy import since 2009 is shown in Table 1.

Table 1.China's traditional energy imports in 2009-2019

\begin{tabular}{|c|c|c|c|}
\hline Year & Gas $/ 10^{9} \mathrm{~m}^{3}$ & Crude $/ 10^{8} \mathrm{t}$ & Coal $/ 10^{8} \mathrm{t}$ \\
\hline 2009 & 7.6 & 2.037 & 1.259 \\
\hline 2010 & 16.5 & 2.377 & 1.648 \\
\hline 2011 & 31.2 & 2.538 & 1.631 \\
\hline 2012 & 42.1 & 2.710 & 2.884 \\
\hline 2013 & 52.5 & 2.817 & 3.270 \\
\hline 2014 & 59.1 & 3.084 & 2.912 \\
\hline 2015 & 61.6 & 3.355 & 2.041 \\
\hline 2016 & 75.3 & 3.810 & 2.555 \\
\hline 2017 & 95.6 & 4.196 & 2.709 \\
\hline 2018 & 126.0 & 4.619 & 2.812 \\
\hline
\end{tabular}




\begin{tabular}{|c|c|c|c|}
\hline 2019 & 134.5 & 5.057 & 2.997 \\
\hline $\begin{array}{c}\text { Average } \\
\text { annual } \\
\text { growth rate }\end{array}$ & $33.29 \%$ & $9.52 \%$ & $9.06 \%$ \\
\hline $\begin{array}{c}\text { Year on year } \\
\text { rate }\end{array}$ & $6.75 \%$ & $9.48 \%$ & $6.58 \%$ \\
\hline
\end{tabular}

Sources: BP World Energy Outlook 2019

The United States was once one of the world's major energy importers. However, after Trump came to power, he encouraged the United States to expand the development and utilization of traditional energy, attempting to use the development of traditional energy to drive the development of American economy. The United States has mastered the advanced technology of shale oil development through the shale oil revolution, which has reduced the production cost of crude oil and natural gas, and the output of crude oil and natural gas in the United States has also increased rapidly. The United States is expected to become the main supplier of global traditional energy in the future. The energy export volume of the United States over the years is shown in Table 2.

Table 2.US traditional energy exports from 2000 to 2018

\begin{tabular}{|c|c|c|c|}
\hline Year & $\begin{array}{c}\text { Gas } \\
/ 10^{9} \mathrm{~m}^{3}\end{array}$ & $\begin{array}{c}\text { Crude } \\
/\left(\mathrm{kbbl} \cdot \mathrm{d}^{-1}\right)\end{array}$ & $\begin{array}{c}\text { Coal } / 10^{6} \mathrm{t} \\
\text { boe }\end{array}$ \\
\hline 2000 & 1.7 & 890 & 38.0 \\
\hline 2005 & 1.9 & 1129 & 31.7 \\
\hline 2010 & 1.5 & 2154 & 49.9 \\
\hline 2011 & 1.8 & 2495 & 62.1 \\
\hline 2012 & 0.8 & 2682 & 73.2 \\
\hline 2013 & 0.2 & 3563 & 70.0 \\
\hline 2014 & 0.4 & 4033 & 59.0 \\
\hline 2015 & 0.7 & 4521 & 46.5 \\
\hline 2016 & 4,0 & 5078 & 36.8 \\
\hline 2017 & 17.2 & 5858 & 59.7 \\
\hline 2018 & 28.4 & 7131 & 66.3 \\
\hline $\begin{array}{c}\text { Average } \\
\text { annual growth } \\
\text { rate }\end{array}$ & $16.9 \%$ & $12.3 \%$ & $3.1 \%$ \\
\hline $\begin{array}{c}\text { Year on year } \\
\text { rate }\end{array}$ & $65.1 \%$ & $21.7 \%$ & $11.1 \%$ \\
\hline
\end{tabular}

Sources: BP World Energy Outlook 2019

The trade war will inevitably bring impact and influence to all walks of life, and the energy industry is difficult to be alone. For many years, the seesaw war between China and the United States has never stopped, and the fundamental contradiction between the two sides has not been resolved. Therefore, the impact of the SinoUS trade war on the energy trade between the two countries can not be underestimated.

\section{The impaction of Sino-US trade war on energy trade between the two countries}

Since Trump came to power in 2018, the U.S. government has regarded China as a strong competitor and imposed large-scale trade sanctions on China. Energy is the cornerstone of a country's survival and development. The
United States has repeatedly made troubles in the energy industry, which has affected the energy trade between China and the United States in many aspects.

\subsection{Oil Industry}

Although oil is not listed separately in the U.S. tax list on China's energy sector, propylene, polyethylene and other related chemical products are listed among them. If these products are taxed, it will certainly hit the oil industry. In 2019, China's crude oil import volume reached $5.057 \times 10^{\wedge} 8 \mathrm{t}$, ranking the first in the world. The tax measures of the United States on China will break the balance of China's crude oil import and export market. Therefore, if the Sino-US trade war cannot be settled in a short period, the relatively stable situation of oil prices in China will be broken, and the risk of domestic oil price plummeting or rising will be greatly increased. In addition, oil is not only an energy product, but also a financial product, so the fluctuation of oil price will have an unpredictable impact on the disputed economy.

\subsection{Gas sector}

In 2019, China's natural gas import volume will reach $1345 \times 10^{\wedge} 8 \mathrm{~m}^{\wedge} 3$, second only to Japan, ranking second in the world. Since 2016, China has imported LNG from the United States. In 2017, China's imports of LNG from the United States reached $4 \%$ of the total. In 2018, after the Sino-US trade war started, China took counter measures and drew up a tax list for the United States, including liquefied natural gas. As a result, the export of liquefied natural gas in the United States has been hit. Although China and the United States have great potential for cooperation in the natural gas industry, it is difficult to carry out cooperation smoothly in the current situation of Sino-US trade war. This is very unfavorable for both countries. China has lost the potential supplier of the United States, and the United States has lost the huge market of China.

\subsection{Coal Industry}

In terms of coal import, there is not much intersection between China and the United States. China's coal imports are mainly from Indonesia, Australia, Mongolia and Russia. In 2018, coal imports from these four countries accounted for nearly $96 \%$ of the total imports, and China's coal imports from the United States accounted for about $1 \%$ of the total. In terms of coal import, China's coal export to the United States is also very low, no more than 1000 tons per year. Therefore, the Sino-US trade war will not have a greater impact on the coal industry. However, in such a context, China still needs to be on guard at all times, and it is best to be fully prepared.

\subsection{Energy Industry Technology and Talents}

In essence, the trade war between China and the United States is the United States' sanctions on China in terms of technology, restricting China's technology research and 
development and innovation. At present, China's energy enterprises are facing the problem of independent innovation and are subject to the control of people in the core technology. In order to change this situation, it is necessary to retain and introduce talents. In terms of talent introduction strategy, China is relatively backward compared with foreign countries. According to statistics, the number of scientific research personnel per million people in each country in 2018 is about 1300 in China and 4400 in the United States. It can be seen that there is still a big gap between China and the United States. The current talent situation is not conducive to the development of China's energy industry.

\section{Countermeasures for China's Energy Industry}

\subsection{Broaden energy import channels to ensure adequate energy supply}

China should strengthen cooperation with other energy import source countries, especially the countries along the belt and road, so as to fill the gap caused by the reduction of energy import from the United States[3]. Energy enterprises should further open up the international market, strengthen cooperation with relevant enterprises in countries along the belt and road, broaden China's energy import channels, and form a diversified energy supply system[4]. At the same time, China should further deepen the energy import cooperation with Russia, EU and other energy countries which are not controlled by the United States, so as to deal with the hegemonic behaviour of the United States.

The government should support one belt, one road, energy and economic cooperation zone. China's energy enterprises should be further supported, and more preferential and supportive measures should be given to energy enterprises. For example, China Development Bank and China Export Import Bank will provide corresponding financial support for overseas investment and construction of energy enterprises. One belt, one road, one belt, one road, should be deepened to promote energy cooperation and promote energy cooperation with Pakistan, Southeast Asia, Asia, Australia and other countries and regions, and promote the implementation of energy free trade zones and investment cooperation projects between the two countries.

\subsection{Accelerate the reform of state-owned enterprises in energy industry and enhance the international competitiveness of products}

Most of China's energy enterprises are state-owned enterprises. In today's Sino-US trade situation, stateowned enterprises will face competition from foreign enterprises and foreign capital in the international market. Therefore, the state-owned enterprises in the energy industry should follow the market-oriented direction, follow the development law of the energy industry, intensify the reform, and support and encourage private enterprises to enter the energy market. The government should strengthen the communication and cooperation between enterprises within and among industries to form industrial clusters. In order to cope with the possible energy shortage caused by Sino US trade war, the energy demand industry should make use of the sharing economic platform, Internet of things and big data information convenience brought by the "Internet plus" national strategy, and strengthen the information sharing, resource complementarity and technology sharing among enterprises in the industry. Through the information exchange platform, the old enterprises give the information and resources to the new enterprises that are difficult to survive. The new enterprises give the old enterprises the innovation and sharing of production technology and management mode, and form industrial clusters to jointly deal with the energy import crisis caused by the trade war.

Seize the wave of world opportunities, develop China's advanced manufacturing industry, firmly grasp the core technology in their own hands, and enhance the international competitiveness of energy products. Try to make sure that even if the related products are restricted in import and export and tariff, China's products can not be replaced by the products of other countries.

\subsection{Increase investment in scientific research, promote energy technology innovation and scientific research personnel training}

Scientific research work is not only long cycle, slow process, but also has great uncertainty, so it needs a longterm, large amount of capital investment to ensure the smooth progress of scientific research activities. In recent years, China's total scientific research expenditure is relatively high, ranking the second in the world, second only to the United States. But in terms of $\mathrm{R} \& \mathrm{D}$ expenditure and GDP, China is still at a low level. In the future, China should increase investment in scientific research, focus on promoting energy technology reform and innovation, attract foreign advanced technology, train domestic scientific research personnel, and minimize the negative impact of Sino-US trade war[5].

We will promote the development of China's advanced manufacturing industries, such as intelligent manufacturing and green manufacturing, and actively negotiate and negotiate with the United States to resolve the Sino US conflicts peacefully. We should increase participation in the fourth industrial revolution, seize the wave of world opportunities, develop China's advanced manufacturing industry, and firmly hold the core technology in our own hands. We should improve the patent system, laws and regulations, fund and financial institutions, crack down on the inhibition of free riding on the development of technology by enterprises, and enhance the influence of made in China in the world market, so as to enhance the sense and identity of domestic consumers towards made in China. 


\subsection{Analyze the core issues of Sino-US trade war and look for the possibility of future cooperation}

The Sino-US trade war has adverse effects on both sides. In this war, both sides have advantages and disadvantages, and there is room for compromise and cooperation. According to the current information, there are three main demands of the United States in provoking the trade war. They are to reduce the trade deficit between China and the United States, hope that China will increase its openness to the U.S. market, and that China must not force foreign enterprises to exchange technology for the Chinese market. China can make concessions to a certain extent in exchange for the corresponding compromise of the United States, so that there is room for negotiation between the two sides.

\section{Conclusion}

To sum up, China and the United States are the largest developing and developed countries in the world. The trade war between the two countries will have a huge impact on China and the United States and even the world. The Sino-US trade war has affected China's energy import from politics, technology, taxation and other fields. This will have a great impact on China's long-term import of natural gas and oil, and then affect China's economic and social development. In this Sino-US trade war, we should learn from the trade war between Japan and the United States, never bow to US hegemonism, actively promote energy technology reform and innovation, promote international energy cooperation in various fields, and enhance the international competitiveness of energy products, so as to eliminate the adverse impact of the SinoUS trade war on China's energy industry, so as to ensure the stable development of China's economy and society Exhibition.

\section{References}

1. Fan, W., Baichuan, S., Wenxiu, X. (2018)Current situation, space and strategy of energy cooperation between China and the United States from the perspective of trade friction. Asia Pacific economy, (6): 55-59.

2. Yue,Q., Xiaoyu, Q., Haigang, H. (2018)The impact of Sino-US trade friction on China's industry and economy: a case study of the US 301 investigation report on China in 2018. China Science and Technology Forum, 5: 128-135.

3. Linna,H. (2019)One belt, one road initiative, China's trade structure optimization research. business economics research, 21: 138-140.

4. Mingting,H. (2017)one belt, one road to China's international trade pattern,. economic analysis, 22: 125-127.

5. Guanqun,M.(2018)The current game and cooperation in energy field between China and the United States. International economic cooperation, 9: 45-53. 